\title{
Analysis of the Contribution of Intellectual Capital to Economic Growth Based on an Empirical Analysis of Prefecture-Level Cities in Guangxi
}

\author{
Qun Zeng, ZhenHai Tan $(\mathbb{D}$, and Chunnian Liu \\ School of Management, Nanchang University, Nanchang 330031, China \\ Correspondence should be addressed to Chunnian Liu; pan81706@163.com
}

Received 1 April 2021; Accepted 29 June 2021; Published 9 July 2021

Academic Editor: Massimiliano Ferrara

Copyright ( 2021 Qun Zeng et al. This is an open access article distributed under the Creative Commons Attribution License, which permits unrestricted use, distribution, and reproduction in any medium, provided the original work is properly cited.

\begin{abstract}
The purpose of this paper is to explore the reasons for the differences in intellectual capital between regions and put forward reasonable suggestions for regional economic development through the use of an intellectual capital measurement model. Based on a sample of 14 cities in Guangxi in 2017, this work builds a set of indicator systems to evaluate intellectual capital contributions. First, the comprehensive intellectual capital score of each region is calculated, and the principal component analysis is used to analyze three elements. Second, a regression equation model between the regional intellectual capital and the regional economic status indicator-GDP-is established, and a descriptive statistical test, a correlation test, and a robustness test are carried out on the model. This work finds that the three major factors of regional intellectual capital have positive effects on the level of regional economic development, among which the contribution of regional structural capital to economic development is the largest, reaching more than $50 \%$, followed by human capital, and, finally, relational capital. The unbalanced characteristics of intellectual capital between cities are quite prominent, and thus, the alleviation of the unbalanced development of cities has become a problem that must be urgently addressed. Structural capital has the highest impact on GDP of all types of capital, with government income from structural capital accounting for more than half of total incomes.
\end{abstract}

\section{Introduction}

For a long period of time, economic development has mainly depended on the use of tangible assets, such as land, natural resources, and equipment, to create value for companies. However, in today's information economy era, the success of economic development depends to some extent on the ability to apply knowledge. As a part of a company's knowledge assets, intellectual capital is an important value driver [1]. The purpose of this study is to analyze the statistical data of 14 cities in Guangxi to construct an intellectual capital measurement model, investigate regional intellectual capital in the regional economy, and examine the influence of the important factors that affect regional economic development. From the perspective of the intellectual capital field, reasonable suggestions are proposed for the development of the regional economy and intellectual capital measurement for the city to provide a more general solution.

In 1836, Senior, a British economist, already put forward the concept of "intellectual capital." He believed that the advanced form of human capital was intellectual capital and that the intellectual capital of an enterprise was the sum of knowledge and skills possessed by its employees that could create value for the enterprise [2]. However, to date, the definition of intellectual capital remains a controversial topic, and academic circles have divided the conceptual description of intellectual capital into three dimensions. At present, the concept of intellectual capital is also widely used in the evaluation of different industries, and it is difficult for scholars to reach a consensus on its definition. However, the concept of "intellectual capital," which is now widely recognized both at home and abroad, was first proposed by the American economist Galbraith. He believed that intellectual 
capital is essentially a process of ideological form and a method for achieving business objectives [3]. At present, the concept of intellectual capital in academic circles in recent years can be divided into the three perspectives shown in Table 1.

In the study of regional intellectual capital, scholars have provided similar definitions and different measurement models for regional, national, and regional intellectual capital. Bradley is one of the first international scholars to apply the concept of regional intellectual capital to the calculation of national wealth and to popularize it. [10]. Andriessen, in model design, used multidimensional measurement theory; considered the three elements of intellectual capital, namely, human capital, structural capital, and relational capital, as well as the three aspects of investment, assets, and their content; and investigated the intellectual capital of European Union countries, which was the first time that intellectual capital theory has been applied on a global scale for national intellectual capital measurement; moreover, this was the first time that the multidimensional value of measurement theory was considered [11]. Garvin was the first to apply the theory of intellectual capital from the perspective of the macroeconomy and comprehensively summarize the relevant theories on regional intellectual capital development, thus creating a new research field for the regional economy [12]. Schiuma et al. defined intellectual capital from the perspective of intangible assets and proposed that intellectual capital is the collection of a series of intangible asset elements, such as knowledge, professional skills, organizational structure, database, customer relationship, employee loyalty, social value, and values. All these intangible asset elements can create value for an organization [13]. Nitkiewicz et al. used the method of data envelopment analysis to evaluate the regional intellectual capital and regional development performance of Poland and found that there was a significant positive correlation between the efficiency score and regional intellectual capital [14].

Research on the intellectual capital of enterprises has always been a hot topic, mainly focusing on the innovation ability of enterprises, knowledge management [15], information disclosure, and enterprise value. Asiaei and Jusoh found that culture and trust affect intellectual capital and organizational performance through partial least squares regression analysis based on CFO data from 128 companies on the Tehran Stock Exchange [16]. Cuozzo et al. classified and analyzed the design/method/method research articles on intellectual capital information disclosure in relevant journals from 2000 to 2017 and summarized the findings [17]. Flower believes that comprehensive reports lack regulatory enforcement [18]. Therefore, unless the IIRC can persuade international regulators to enforce consolidated reporting under International Financial Reporting Standards (IFRS) or Generally Accepted Accounting Principles (GAAP) as a mandatory form of financial reporting, it will be difficult for consolidated reporting to become a reporting standard. Guthrie et al. explore the voluntary declaration of intellectual capital by listed companies in Australia and Hong Kong and explore the impact of size, industry, and timing on the level of intellectual capital disclosure [19].
This research is based on the research of domestic and foreign scholars and analyzes the city-level contribution of intellectual capital to economic growth, which is more inclined to the calculation of a large area; thus, most of the intellectual capital research has focused on either provincial units and developed areas or inland cities and underdeveloped areas to identify the contribution of intellectual capital to economic growth. At present, the research on regional intellectual capital mainly focuses on the comparison of different levels of regional intellectual capital, the influence of intellectual capital on regional innovation ability, and the discussion on the measurement construction of regional intellectual capital $[14,15]$. However, the research on the influence of regional intellectual capital on economic development focuses more on a large area rather than a city. Therefore, on the basis of previous studies $[9,11]$, this paper constructs a more universal regional intellectual capital measurement model to measure the regional intellectual capital of all cities in Guangxi and reveals the reasons for the imbalance of intellectual capital among cities. The content of intellectual capital at the regional level goes far beyond patents, copyrights, and other forms of intellectual property that can be acquired simultaneously within an industry or enterprise, as well as the knowledge and experience contained in the human brain. In this paper, regional intellectual capital is defined as being made up of human capital, structural capital, and relational capital. Intellectual capital is defined as the "things related to intellectual factors-knowledge, information, intellectual property and experience-that can be used to create social value." Combining the view of intellectual capital research both at home and abroad, this paper argues that regional intellectual capital is related to mental health factors-strength, health, and experience, knowledge, and technology accumulation, as well as individuals, families, groups, and areas with other qualities - and that, in its development, it can create value for regional economic output. Therefore, in this article about the meaning and form based on the research of regional intellectual capital $[8,9,20]$, according to data from the local bureau of statistics released by the statistics, 14 cities in Guangxi were selected to be analyzed in 2017. According to national and domestic intellectual capital, a set of index systems for these 14 cities in Guangxi was built considering regional economic development, and a demonstration analysis of the relationships between these 14 cities in terms of regional intellectual capital was performed. This paper evaluates the contribution of the three main factors of intellectual capital to regional economic growth, discusses how to solve the unbalanced economic development of different prefecture-level cities in Guangxi, and narrows the gap in the literature on intellectual capital across regions.

\section{Materials and Methods}

With the emergence of the Internet of Things in the 21st century, the importance of intellectual capital in social and economic development has been increasing. According to the resource-based view, the tangible and intangible resources of enterprises can be transformed into unique 
TABLE 1: The concept of intellectual capital.

\begin{tabular}{|c|c|c|}
\hline Perspective & Presenter & Content \\
\hline \multirow{3}{*}{$\begin{array}{l}\text { Ability or } \\
\text { knowledge }\end{array}$} & Stewart & $\begin{array}{l}\text { Intellectual capital can be summarized as the sum of things known to the employees of an } \\
\text { enterprise that can improve its market competitive advantage and its utilization efficiency of } \\
\text { various resources [4] }\end{array}$ \\
\hline & Kujansivu & $\begin{array}{l}\text { All of the knowledge about the concept of resource comprehensive is intellectual capital, similar } \\
\text { to a variety of effective approaches to the utilization of resources of the enterprise and } \\
\text { organization, the latest patent and production equipment, reasonable use of employee and } \\
\text { enterprise effective management mode, etc.; it includes both the advantage of enterprises in } \\
\text { obtaining competitive advantage resources but can also solve the problem of enterprise strategy, } \\
\text { method, and mental models [5] }\end{array}$ \\
\hline & Ghoshal & $\begin{array}{c}\text { This is the sum of all intangible assets within an enterprise, including employees' skill level, } \\
\text { knowledge, experience, information, and attitude [6] }\end{array}$ \\
\hline \multirow{3}{*}{ Intangible assets } & Annie Brooking & $\begin{array}{l}\text { Intellectual capital can be equated to intangible assets, including all nontangible assets such as the } \\
\text { knowledge, property rights, and technology required for enterprise operation [7] }\end{array}$ \\
\hline & Masoulas & $\begin{array}{l}\text { Intellectual capital is the combination of intangible assets; it is believed that intellectual capital } \\
\text { encompasses all intangible assets, including the sum of personal skills, past experience, working } \\
\text { attitude, and production information of the employees of the company; organizations can use } \\
\text { intellectual capital to make use of intangible assets to improve value added to improve } \\
\text { organizational value [6] }\end{array}$ \\
\hline & Lu et al. & $\begin{array}{l}\text { Intellectual capital is an invisible asset, namely, an intangible asset; although it is difficult to fully } \\
\text { express it in words, it does play a crucial role in the development of a country [8] }\end{array}$ \\
\hline \multirow[b]{2}{*}{ Value } & OECD & $\begin{array}{c}\text { The economic value embodied by the coupling of structure and human capital is intellectual } \\
\text { capital }\end{array}$ \\
\hline & $\begin{array}{l}\text { Edvinsson and } \\
\quad \text { Sullivan }\end{array}$ & $\begin{array}{l}\text { Intellectual capital is defined as the potential resources that create earnings and profits for an } \\
\text { enterprise; the specific calculation formula is that the market value of an enterprise is subtracted } \\
\text { from its book value, and the difference value is the intangible intellectual capital [9] }\end{array}$ \\
\hline
\end{tabular}

market competitive advantages to ensure that enterprises can dominate in terms of modern market competition. Similarly, the strength of regional competitiveness is determined by the development level of regional intellectual capital and its components. Whether intellectual capital can have a positive effect on the development of the regional economy still needs empirical testing. Do the three elements of regional intellectual capital have the same effect on the promotion of the development of intellectual capital? Which element has a decisive effect on regional economic prosperity? First, according to Chen et al.'s [20] index design of the scheme of intellectual capital, in the case of a comprehensive practical design, as shown in Table 2, SPSS software was used for the analysis of the intellectual capital of the Guangxi Zhuang Autonomous Region. Fourteen cities were used to analyze the three elements of regional human capital, structural capital, and relational capital, and principal component analysis (PCA) was used to evaluate the score calculation and analyze the correlation of internal relations. Second, regression analysis between the standardized value and the standardized GDP value of the three elements of regional intellectual capital was carried out, and multiple regression equations among regional human capital, regional structural capital, regional relational capital, and regional GDP were constructed. Then, through the descriptive test of the original value of the regional human capital, regional structural capital, and regional relational capital of these 14 prefecture-level cities, we found the capital that contributes the most to the GDP level of the Guangxi Zhuang Autonomous Region and revealed the imbalance of the regional intellectual capital level of these 14 prefecture-level cities in Guangxi. Finally, variable correlation analysis and robustness analysis were carried out to verify the reliability, credibility, and feasibility of the regression equation model.

Since the concept of intellectual capital was put forward, scholars at home and abroad have given different explanations for the meaning of intellectual capital from different angles. As far as the present study is concerned, the composition of independent capital mainly concentrates on dualism, ternary theory, and so on. In dualism, intellectual capital is generally divided into human capital and structural capital following the method of Edvinsson and Malone [8]. Generally, ternary theory refers to the H-S-C structure proposed by the American scholar Stewart in 1997 and is widely recognized. It is believed that human capital, structural capital, and customer capital constitute the concept of intellectual capital. However, different scholars have different definitions or names for these three types of capital. The concept of regional intellectual capital used in this paper is composed of human capital, structural capital, and relational capital, which are all derived from previous research [14]. The content of regional human capital includes the medical and health level, education and research level, and social security level. The content of regional structural capital generally includes the level of material exchange between regions, the level of material flow within regions, and the mechanism of regional communication and information exchange and circulation. Regional relational capital generally includes personnel flow between regions, domestic personnel exchange, and social consumption level, as well as capital investment in foreign countries or international exchanges. 
Table 2: Three-tier index system of intellectual capital.

\begin{tabular}{|c|c|c|c|c|}
\hline $\begin{array}{l}\text { First-order } \\
\text { index }\end{array}$ & $\begin{array}{l}\text { Second-order } \\
\text { index }\end{array}$ & Third-order index & Evaluation index & Unit \\
\hline \multirow{17}{*}{$\begin{array}{l}\text { Intellectual } \\
\text { capital }\end{array}$} & \multirow{8}{*}{ Human capital } & \multirow{3}{*}{ Education level } & Primary pupil-to-student ratio (X11) & $\%$ \\
\hline & & & Regular high school student-to-student ratio (X12) & $\%$ \\
\hline & & & $\begin{array}{l}\text { Student-to-student ratio of institutions of higher learning } \\
\text { (X13) }\end{array}$ & $\%$ \\
\hline & & \multirow{3}{*}{ Health security } & $\begin{array}{c}\text { Number of medical institution beds per 1,000 people } \\
\text { (X14) }\end{array}$ & Per person \\
\hline & & & Number of health technicians per 1,000 people (X15) & Per person \\
\hline & & & $\begin{array}{c}\text { Practicing (assistant) medical practitioners per } 1,000 \\
\text { people (X16) }\end{array}$ & Per person \\
\hline & & & Number of registered nurses per 1,000 people (X17) & Per person \\
\hline & & Transportation & Per-capita urban road area (X21) & Square meters \\
\hline & \multirow{3}{*}{ Structural capital } & \multirow{3}{*}{$\begin{array}{l}\text { Regional } \\
\text { communication }\end{array}$} & Total post and telecommunication services (X22) & $\begin{array}{l}\text { Ten thousand } \\
\text { RMB }\end{array}$ \\
\hline & & & $\begin{array}{l}\text { Number of mobile phone subscribers per 10,000 } \\
\text { households at year-end (X23) }\end{array}$ & Per person \\
\hline & & & Fixed-line subscribers per 10,000 households (X24) & Per person \\
\hline & \multirow{6}{*}{$\begin{array}{l}\text { Relationship } \\
\text { capital }\end{array}$} & Personnel exchange & Domestic tourism revenue (X31) & $\begin{array}{l}\text { Ten thousand } \\
\text { RMB }\end{array}$ \\
\hline & & \multirow[b]{2}{*}{ Domestic trade } & Total retail sales of consumer goods (X32) & $\begin{array}{l}\text { Ten thousand } \\
\text { RMB }\end{array}$ \\
\hline & & & Domestic tourist numbers (X33) & $\begin{array}{l}\text { Ten thousand } \\
\text { dollars }\end{array}$ \\
\hline & & \multirow{3}{*}{ International trade } & $\begin{array}{l}\text { Foreign exchange earnings from international tourism } \\
\qquad \text { (X34) }\end{array}$ & $\begin{array}{l}\text { Ten thousand } \\
\text { dollars }\end{array}$ \\
\hline & & & Foreign direct investment (X35) & $\begin{array}{l}\text { Ten thousand } \\
\text { dollars }\end{array}$ \\
\hline & & & Actual utilization of foreign capital (X36) & $\begin{array}{l}\text { Ten thousand } \\
\text { dollars }\end{array}$ \\
\hline
\end{tabular}

Based on international and domestic research on regional intellectual capital, this paper adopts the widely used $\mathrm{H}-\mathrm{S}-\mathrm{C}$ structure proposed by the American scholars Myers and Turnbull [1] in 1997 and classifies the components of regional intellectual capital into the following three aspects: regional human capital, regional structural capital, and regional relational capital. Therefore, the index system design of this paper also revolves around these three aspects. First, the difficulty of obtaining statistical data was considered, and then the index system proposed by the foreign and domestic scholars Wang Xuejun and Chen $\mathrm{Wu}$, respectively, was referenced. Therefore, this work builds a three-tier index system from these three perspectives, as shown in Table 2.

As shown in Table 2, the index system in 2017 of these 14 prefecture-level cities (cities and districts) in Guangxi was selected as the sample. The data came from the Guangxi Statistical Yearbook and the statistical yearbook of each prefecture-level city, and the values of each index in the index system of the above 14 regions were obtained through calculation. For the problem of missing values in statistical data, missing value analysis via SPSS can be used to supplement the missing values in the original data as shown in Figure 1.

\section{Results and Discussion}

\subsection{Evaluation of the Intellectual Capital of 14 Prefecture-Level Cities in Guangxi}

3.1.1. Evaluation Results of Regional Human Capital (X1). First, the KMO test is conducted on regional human capital, and the test value is 0.627 (greater than 0.6). The chi-square of Bartlett's sphere test is 136.998, and its significance probability is 0.000 , which is less than $1 \%$, indicating that regional human capital is suitable for factor analysis. Second, for regional human capital, factor analysis (principal component analysis) is performed to extract the common factor, as it is the factor rotation method with the largest variance. This method (Varimax) using SPSS statistical analysis was carried out on the evaluation index and the three public factors extracted from original data, which account for $58.267 \%, 21.330 \%$, and $14.666 \%$ of the total variation, explaining $94.263 \%$ of the total variation. Then, according to the factor scoring coefficient matrix output by the factor analysis, the scoring function of the seven common factors of regional human capital is obtained, and the specific scores of the three common factors are calculated according to the 


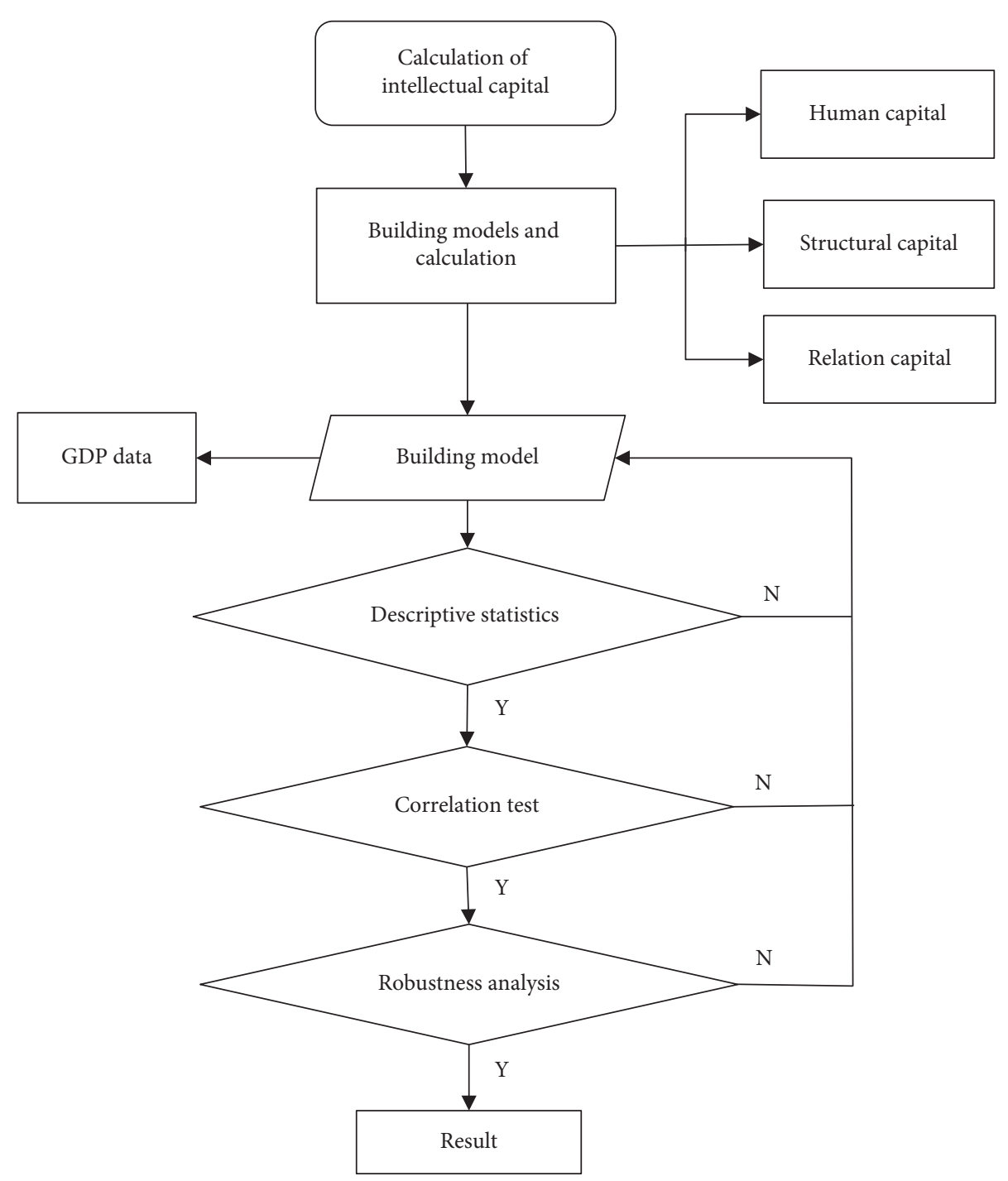

Figure 1: Calculation steps of the intellectual capital index system and related results.

factor scoring function. The comprehensive score of the human capital of each region is obtained by weighting the obtained factor scores. The formula [20] for calculating the weight of each factor is as follows (FVCR: factor variance contribution rate; TCVCR: total cumulative variance contribution rate):

$$
H_{i}=\frac{\mathrm{FVCR}}{\mathrm{TCVCR}} * 100 \%
$$

Finally, according to (1) and the data of the total variance decomposition table, the weights of the three common factors, $H_{1}, H_{2}$, and $H_{3}$, are calculated as $61.81 \%, 22.63 \%$, and $15.56 \%$, respectively. Therefore, the formula for calculating the comprehensive score of regional human capital is as follows:

$$
X_{1}=0.6181 * H_{1}+0.2263 * H_{2}+0.1556 * H_{3} .
$$

According to (2), the comprehensive score value of the human capital of 14 prefecture-level cities is calculated. Then, the overall score is standardized, as shown in Table 3.
3.1.2. Evaluation Results of Regional Structural Capital (X2). First, missing value analysis is used to supplement the missing values in the structural capital data.

Then, the KMO test is conducted on regional human capital, and the test value is 0.622 . The chi-square of Bartlett's sphere test is 68.883 , and its significance probability is 0.000 , which is less than $1 \%$, indicating that regional structural capital is suitable for factor analysis. By a statistical analysis of the evaluation index values, a common factor is extracted from the original data, which accounts for $78.117 \%$ of the total variation. The output according to the factor analysis of the factor score coefficient matrix can include the regional common factors of the capital structure of the original variable factor score function. Moreover, the score for a common factor can be calculated, because through factor analysis, only one common factor can be extracted, so we do not need to weight the scores to directly obtain the structure of regional capital, standardized with composite scores, as shown in Table 3. 
TABLE 3: Scores for intellectual capital evaluation.

\begin{tabular}{|c|c|c|c|c|c|}
\hline Region & Human capital & Structural capital & Relational capital & Intellectual capital scores & Rankings \\
\hline Nanning city & 2.37305 & 3.06717 & 2.87011 & 8.31033 & 1 \\
\hline Liuzhou city & 1.76923 & 0.46331 & 0.71501 & 2.94755 & 2 \\
\hline Guilin city & 0.43042 & 0.61762 & 1.1875 & 2.23554 & 3 \\
\hline Wuzhou city & 0.015 & -0.46782 & -0.35093 & -0.80375 & 7 \\
\hline Beihai city & 0.31017 & -0.51525 & -0.36101 & -0.56609 & 5 \\
\hline Fangchenggang city & 0.23549 & -0.8998 & -0.80784 & -1.47215 & 10 \\
\hline Qinzhou city & -0.65495 & 0.07216 & -0.36489 & -0.94768 & 8 \\
\hline Guigang city & -1.08233 & -0.07209 & -0.32317 & -1.47759 & 11 \\
\hline Yulin city & -0.96336 & 0.31189 & 0.22171 & -0.42976 & 4 \\
\hline Baise city & -0.18271 & -0.19233 & -0.38009 & -0.75513 & 6 \\
\hline Hezhou city & -0.61172 & -0.77158 & -0.59469 & -1.97799 & 13 \\
\hline Hechi city & -0.33052 & -0.30031 & -0.41305 & -1.04388 & 9 \\
\hline Laibin city & -0.67457 & -0.72801 & -0.72539 & -2.12797 & 14 \\
\hline Chongzuo city & -0.63322 & -0.58495 & -0.67327 & -1.89144 & 12 \\
\hline
\end{tabular}

3.1.3. Evaluation Results of Regional Relational Capital (X3). The KMO test is performed to analyze regional relational capital, and the test value is 0.667. The chi-square of Bartlett's sphere test is 111.439 , and its significance probability is 0.000 , which is less than $1 \%$, indicating that regional relational capital is suitable for factor analysis. Through the statistical analysis of the evaluation index values, two common factors are extracted from the original data. The two common factors explain $66.275 \%$ and $24.428 \%$ of the total variation and $90.703 \%$ of the total accumulative variation. According to the factor scoring coefficient matrix output by the factor analysis, the original variable factor scoring function of the common factor is obtained, and the specific scores of the two common factors are calculated according to the factor scoring function. The weighted calculation of the obtained factor scores is carried out to obtain the comprehensive score of the structural capital of each region. According to the equation and the data of the total variance decomposition table (omitted), the weights of two common factors, $S_{1}$ and $S_{2}$, are calculated as $73.068 \%$ and $26.932 \%$, respectively. Therefore, the formula for calculating the comprehensive score of regional structural capital is as follows:

$$
X_{3}=0.73068 * S_{1}+0.26932 * S_{2} .
$$

According to the above formula, the comprehensive scores for the regional relational capital of 14 prefecturelevel cities are calculated, and the comprehensive score is standardized, as shown in the table.

3.1.4. Fourteen Prefecture-Level Cities Scored in terms of Intellectual Capital. The above three steps can be used to calculate the weighted comprehensive evaluation scores of the regional human capital, regional structural capital, and regional relational capital of the 14 prefecture-level cities in Guangxi. After standardization, the comprehensive scores of the regional intellectual capital of each city can be obtained, as shown in Table 3. The higher the comprehensive score of a region is, the stronger the regional intellectual capital level of the region is.

\subsection{Regression Equation Model of Intellectual Capital and Urban GDP}

3.2.1. Correlation Analysis of the Degree of Economic Development and Regional Intellectual Capital of 14 PrefectureLevel Cities in Guangxi. Using SPSS, Pearson correlation analysis, Kendall correlation analysis, and Spearman correlation analysis were conducted on the GDP of 14 different cities in Guangxi and the regional intellectual capital scores of each prefecture-level city, the correlation coefficients of which were $0.973,0.802$, and 0.930 , respectively, which were all significant at the $1 \%$ level.

The results of different correlation analyses show that regional intellectual capital has an obvious positive correlation with GDP, which indicates that it has a great influence on regional economic development. The promotion of regional economic development and improvement of the regional intellectual capital level can enhance regional competitiveness and thus promote regional economic development. In addition, the correlation coefficients of the three different correlation analyses between the level of regional economic development and the level of the three local intellectual capital elements in the 14 cities in Guangxi are all more than 0.8 , indicating the contribution of intellectual capital elements to the level of economic development in the 14 cities and the high reliability of the model analysis. Then, this work analyzes the specific contribution of the three main components of regional intellectual capital to the economic development of Guangxi.

3.2.2. The Contribution of the Three Components of Regional Intellectual Capital to the Economic Development of Guangxi. Using SPSS, this paper establishes a regression analysis model between the standardized weighted comprehensive scores of the human capital, structural capital, and relational capital of 14 prefecture-level cities in Guangxi in 2017 and the city GDP in that year after standardization and discusses the relationship between the economic development of these 14 prefecture-level cities in Guangxi and the three components of regional intellectual capital. The establishment of the econometric model is as follows [20]: 


$$
\mathrm{ZGDP}=\partial_{1} * X_{1}+\partial_{2} * X_{2}+\partial_{3} * X_{3}+\epsilon .
$$

Using SPSS to conduct regression analysis on the above model, the following results can be obtained:

$$
\mathrm{ZGDP}=0.315 * X_{1}+0.548 * X_{2}+0.178 * X_{3} .
$$

$X_{1}$ is the weighted comprehensive score of human capital, $X_{2}$ is the weighted comprehensive score of structural capital, and $X_{3}$ is the weighted comprehensive score of related capital.

According to the model analysis, the adjusted $R^{2}$ value is 0.936 , indicating that the regression relationship can explain 93.6\% of the variation in GDP data. The value of the Durbin-Watson (DW) statistic is 1.892 , which is between 0 and 2 and close to 2 ; thus, the residual sequence has positive autocorrelation.

The $\mathrm{F}$ value of the regression model is 64.803 , and the significance level is 0.000 , which indicates that the linear relationship of the regression equation is significant. The $t$ test values of human capital, structural capital, and relational capital are 2.677, 1.857, and 0.532, respectively, and their significance is $0.023,0.093$, and 0.607 at the $1 \%$ level. Under the given significance level of $1 \%$, both human capital and structural capital are significant. For relational capital, $P=0.607>0.1$, and thus it is not significant.

The above model analysis results show that the three major elements of regional intellectual capital-human capital, structural capital, and relational capital-all have a positive influence on regional economic growth; the contribution of regional structural capital to economic development is the largest, reaching more than $50 \%$; and the regression coefficient is significant at the $1 \%$ level. The regression coefficient of regional human capital is the second largest, and the regression coefficient is very significant, which indicates that it has a great contribution to regional GDP. The regression coefficient of regional relational capital is the smallest, and the $t$-test value shows that the regional relational capital coefficient is not significant at the $1 \%$ level.

\section{Model Test}

4.1. Descriptive Statistics. Table 4 shows the descriptive statistical results of the original values of the three major components of intellectual capital-human capital, structural capital, and relational capital. As shown in Table 4, the mean values of human capital, structural capital, and relational capital are 18.3410; 181,474.9943; and 1,753,447.102, respectively; that is, the mean value of the human capital score is the lowest, but this does not mean that the role of human capital is far less than that of structural capital and relational capital. The minimum value of human capital is 12.09 , the maximum value is 32.06 , and the gap between the two is more than twofold, which is far less than the gap between the maximum and minimum values of structural capital and relational capital. The overall gap in human capital between the 14 prefecture-level cities is not large, and the gap between the maximum and minimum values of structural capital and relational capital is approximately tenfold. The gap in intellectual capital between different prefecture-level cities is mainly reflected in structural capital and relational capital.

\subsection{Correlation Analysis of Variables}

4.2.1. Correlation of Human Capital Variables. Table 5 shows the results of the Pearson correlation test on the human capital research variables. As seen from the table, the Pearson correlations between the teacher-to-student ratio in primary schools and the other six variables are all lower than 0.8 , and the $P$ values of the two-tailed test probability are all greater than 0.05 . Therefore, there is no significant correlation between the teacher-to-student ratio in primary schools and the other six variables at the $1 \%$ level. The Pearson correlations between the student-to-student ratio of ordinary high schools and that of colleges and universities and the other six variables are lower than 0.8 , and the $P$ value of the two-tailed test probability is greater than 0.05 . Therefore, the student-to-student ratio of general high schools and that of colleges and universities do not show a significant correlation with the other six variables at the $1 \%$ level. For four variables-number of beds per one thousand people, number of technical health personnel per one thousand people, number of practicing (assistant) doctors per one thousand people, and number of registered users per one thousand people-the Pearson correlation coefficients are greater than 0.8 and the $P$ values are 0.05 ; thus, the student-to-faculty ratios in elementary schools and the other six variables are significant at the $1 \%$ level. In addition, the correlation degree of the primary school student-to-student ratio, regular high school student-to-student ratio, and college student-to-student ratio with other variables is lower than 0.5 , indicating that there is no serious multicollinearity problem among these variables. However, the correlation degree of the number of beds in medical institutions, the number of health technicians, the number of licensed (assistant) physicians, and the number of registered nurses per 1,000 people is higher than 0.5 , indicating that there may be some multicollinearity among these variables. In summary, the independence between the two three-level indicators of education level and health security is relatively reliable, but there are serious collinearity problems in both of these indicators, so an index can be selected or synthesized from the indexes below.

4.2.2. Correlation of Structural Capital Variables. As shown in Table 6, the structural capital results show that the Pearson correlation coefficient of the per-capita urban road area and the other three variables is below 0.8 , with a two-tailed $P$ value greater than 0.05 , and so the per-capita urban road area and other three variables-the number of year-end mobile phone users per 10,000 households, the number of fixed phone users per 10,000 households, and the total number of postal and telecommunications services of ten thousand yuan (TREND)-show significant correlations at the $1 \%$ level. The Pearson correlations between the above three variables are all greater than 0.8 , and the $P$ values of the 


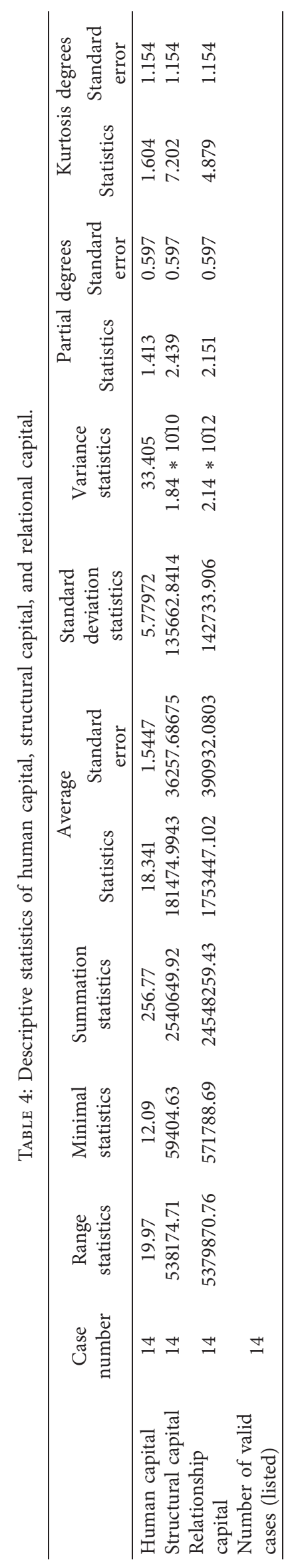


TABLE 5: Human capital correlation test.

\begin{tabular}{|c|c|c|c|c|c|c|c|c|}
\hline & & $\begin{array}{l}\text { Teacher-to- } \\
\text { student } \\
\text { ratio in } \\
\text { primary } \\
\text { schools }\end{array}$ & $\begin{array}{l}\text { Teacher-to- } \\
\text { student ratio } \\
\text { in regular } \\
\text { high schools }\end{array}$ & $\begin{array}{l}\text { Teacher-to- } \\
\text { student ratio in } \\
\text { institutions of } \\
\text { higher learning }\end{array}$ & $\begin{array}{l}\text { Number of } \\
\text { medical } \\
\text { facility beds } \\
\text { per } 1,000 \\
\text { people }\end{array}$ & $\begin{array}{l}\text { Number of } \\
\text { health } \\
\text { technicians per } \\
1,000 \text { people }\end{array}$ & $\begin{array}{c}\text { Number of } \\
\text { licensed } \\
\text { (associate) } \\
\text { physicians per } \\
\text { 1,000 people }\end{array}$ & $\begin{array}{l}\text { Number of } \\
\text { registered } \\
\text { nurses per } \\
1,000 \text { people }\end{array}$ \\
\hline \multirow{3}{*}{$\begin{array}{l}\text { Teacher-to- } \\
\text { student ratio in } \\
\text { primary schools }\end{array}$} & $\mathrm{PC}$ & 1 & 0.067 & -0.467 & 0.221 & 0.372 & 0.303 & 0.366 \\
\hline & S & 0.82 & 0.092 & 0.448 & 0.19 & 0.292 & 0.198 & \\
\hline & $\mathrm{CN}$ & 14 & 14 & 14 & 14 & 14 & 14 & 14 \\
\hline \multirow{3}{*}{$\begin{array}{l}\text { Teacher-to- } \\
\text { student ratio in } \\
\text { regular high } \\
\text { schools }\end{array}$} & PC & 0.067 & 1 & 0.374 & -0.067 & 0.016 & 0.015 & 0.03 \\
\hline & S & 0.82 & 0.187 & 0.819 & 0.956 & 0.959 & 0.916 & \\
\hline & $\mathrm{CN}$ & 14 & 14 & 14 & 14 & 14 & 14 & 14 \\
\hline \multirow{3}{*}{$\begin{array}{l}\text { Teacher-to- } \\
\text { student ratio in } \\
\text { institutions of } \\
\text { higher learning } \\
\end{array}$} & PC & -0.467 & 0.374 & 1 & -0.028 & -0.1 & -0.112 & -0.083 \\
\hline & S & 0.092 & 0.187 & 0.924 & 0.735 & 0.703 & 0.777 & \\
\hline & $\mathrm{CN}$ & 14 & 14 & 14 & 14 & 14 & 14 & 14 \\
\hline \multirow{3}{*}{$\begin{array}{l}\text { Number of } \\
\text { medical facility } \\
\text { beds per } 1,000 \\
\text { people }\end{array}$} & PC & 0.221 & -0.067 & -0.028 & 1 & $0.972^{* *}$ & $0.953^{* *}$ & $0.974^{* *}$ \\
\hline & S & 0.448 & 0.819 & 0.924 & 0 & 0 & 0 & \\
\hline & $\mathrm{CN}$ & 14 & 14 & 14 & 14 & 14 & 14 & 14 \\
\hline \multirow{3}{*}{$\begin{array}{l}\text { Number of } \\
\text { health } \\
\text { technicians per } \\
1,000 \text { people }\end{array}$} & $\mathrm{PC}$ & 0.372 & 0.016 & -0.1 & $0.972^{* *}$ & 1 & $0.984^{* *}$ & $0.997^{* *}$ \\
\hline & S & 0.19 & 0.956 & 0.735 & 0 & 0 & 0 & \\
\hline & $\mathrm{CN}$ & 14 & 14 & 14 & 14 & 14 & 14 & 14 \\
\hline \multirow{3}{*}{$\begin{array}{l}\text { Number of } \\
\text { licensed } \\
\text { (associate) } \\
\text { physicians per } \\
1,000 \text { people }\end{array}$} & PC & 0.303 & 0.015 & -0.112 & $0.953^{* *}$ & $0.984^{* *}$ & 1 & $0.974^{* *}$ \\
\hline & S & 0.292 & 0.959 & 0.703 & 0 & 0 & 0 & \\
\hline & $\mathrm{CN}$ & 14 & 14 & 14 & 14 & 14 & 14 & 14 \\
\hline \multirow{3}{*}{$\begin{array}{l}\text { Number of } \\
\text { registered nurses } \\
\text { per } 1,000 \text { people }\end{array}$} & PC & 0.366 & 0.031 & -0.083 & $0.974^{* *}$ & $0.997^{* *}$ & $0.974^{* *}$ & 1 \\
\hline & $S$ & 0.198 & 0.916 & 0.777 & 0 & 0 & 0 & \\
\hline & $\mathrm{CN}$ & 14 & 14 & 14 & 14 & 14 & 14 & 14 \\
\hline
\end{tabular}

${ }^{* *}$ At the 0.01 level (two-tailed), the correlation is significant; PC: Pearson correlation; S: significance (two-tailed); CN: the case number.

TABLE 6: Correlation test of structural capital.

\begin{tabular}{|c|c|c|c|c|c|}
\hline & & $\begin{array}{l}\text { Per-capita } \\
\text { urban road } \\
\text { area (square } \\
\text { meters) } \\
\end{array}$ & $\begin{array}{l}\text { Year-end number of } \\
\text { mobile phone } \\
\text { subscribers per } 10,000 \\
\text { units }\end{array}$ & $\begin{array}{l}\text { Number of fixed- } \\
\text { line subscribers } \\
\text { per } 10,000\end{array}$ & $\begin{array}{l}\text { Total volume of postal and } \\
\text { telecommunications services of } \\
\text { RMB 10,000 (TREND) }\end{array}$ \\
\hline \multirow{3}{*}{$\begin{array}{l}\text { Per-capita urban road area } \\
\text { (square meters) }\end{array}$} & $\mathrm{PC}$ & 1 & -0.464 & -0.298 & -0.382 \\
\hline & S & 0.095 & 0.301 & 0.177 & \\
\hline & $\mathrm{CN}$ & 14 & 14 & 14 & 14 \\
\hline \multirow{3}{*}{$\begin{array}{l}\text { Year-end number of mobile } \\
\text { phone subscribers per } 10,000 \\
\text { units }\end{array}$} & $\mathrm{PC}$ & -0.464 & 1 & $0.957^{* *}$ & $0.977^{* *}$ \\
\hline & $\mathrm{S}$ & 0.095 & 0 & 0 & \\
\hline & $\mathrm{CN}$ & 14 & 14 & 14 & 14 \\
\hline \multirow{3}{*}{$\begin{array}{l}\text { Number of fixed-line subscribers } \\
\text { per } 10,000\end{array}$} & $\mathrm{PC}$ & -0.298 & $0.957^{* *}$ & 1 & $0.944^{* *}$ \\
\hline & $\mathrm{S}$ & 0.301 & 0 & 0 & \\
\hline & $\mathrm{CN}$ & 14 & 14 & 14 & 14 \\
\hline \multirow{3}{*}{$\begin{array}{l}\text { Total volume of postal and } \\
\text { telecommunications services of } \\
\text { RMB 10,000 (TREND) }\end{array}$} & $\mathrm{PC}$ & -0.382 & $0.977^{* *}$ & $0.944^{* *}$ & 1 \\
\hline & S & 0.177 & 0 & 0 & \\
\hline & $\mathrm{CN}$ & 14 & 14 & 14 & 14 \\
\hline
\end{tabular}

${ }^{* *}$ At the 0.01 level (two-tailed), the correlation is significant. PC: Pearson correlation. S: significance (two-tailed). CN: the case number.

two-tailed test probabilities are all smaller than 0.05 . Therefore, the pair correlation between the above three variables is significant at the $1 \%$ level. In addition, the correlation degree between per-capita urban road area and the other three variables is less than 0.5 , indicating that there is no serious multicollinearity problem among these 
TABLE 7: Relationship test of structural capital.

\begin{tabular}{|c|c|c|c|c|c|c|c|}
\hline & & $\begin{array}{l}\text { Domestic } \\
\text { tourism } \\
\text { income (ten } \\
\text { thousand } \\
\text { yuan) }\end{array}$ & $\begin{array}{l}\text { Total retail sales } \\
\text { of consumer } \\
\text { goods (ten } \\
\text { thousand yuan) }\end{array}$ & $\begin{array}{c}\text { Number of } \\
\text { domestic } \\
\text { tourists } \\
(10,000 \text { person } \\
\text { times) }\end{array}$ & $\begin{array}{l}\text { Foreign exchange } \\
\text { income from } \\
\text { international tourism } \\
\text { (ten thousand US } \\
\text { dollars) }\end{array}$ & $\begin{array}{l}\text { Foreign direct } \\
\text { investment (ten } \\
\text { thousand US } \\
\text { dollars) }\end{array}$ & $\begin{array}{c}\text { Actual } \\
\text { utilization of } \\
\text { foreign capital } \\
\text { (ten thousand } \\
\text { US dollars) }\end{array}$ \\
\hline \multirow{3}{*}{$\begin{array}{l}\text { Domestic tourism } \\
\text { income (ten } \\
\text { thousand yuan) }\end{array}$} & PC & 1 & $0.888^{* *}$ & $0.992^{* *}$ & $0.636^{*}$ & $0.670^{* *}$ & 0.268 \\
\hline & S & 0 & 0 & 0.015 & 0.009 & 0.355 & \\
\hline & $\mathrm{CN}$ & 14 & 14 & 14 & 14 & 14 & 14 \\
\hline \multirow{3}{*}{$\begin{array}{l}\text { Total retail sales of } \\
\text { consumer goods (ten } \\
\text { thousand yuan) }\end{array}$} & PC & $0.888^{* *}$ & 1 & $0.899^{* *}$ & 0.314 & $0.879^{* *}$ & 0.523 \\
\hline & S & 0 & 0 & 0.274 & 0 & 0.055 & \\
\hline & $\mathrm{CN}$ & 14 & 14 & 14 & 14 & 14 & 14 \\
\hline \multirow{3}{*}{$\begin{array}{l}\text { Number of domestic } \\
\text { tourists }(10,000 \\
\text { person times })\end{array}$} & PC & $0.992^{* *}$ & $0.899^{* *}$ & 1 & $0.593^{*}$ & $0.692^{* *}$ & 0.257 \\
\hline & $\mathrm{S}$ & 0 & 0 & 0.026 & 0.006 & 0.375 & \\
\hline & $\mathrm{CN}$ & 14 & 14 & 14 & 14 & 14 & 14 \\
\hline \multirow{3}{*}{$\begin{array}{l}\text { Foreign exchange } \\
\text { income from } \\
\text { international tourism } \\
\text { (ten thousand US } \\
\text { dollars) }\end{array}$} & PC & $0.636^{*}$ & 0.314 & $0.593^{*}$ & 1 & -0.002 & -0.062 \\
\hline & $S$ & 0.015 & 0.274 & 0.026 & 0.994 & 0.833 & \\
\hline & $\mathrm{CN}$ & 14 & 14 & 14 & 14 & 14 & 14 \\
\hline \multirow{3}{*}{$\begin{array}{l}\text { Foreign direct } \\
\text { investment (ten } \\
\text { thousand US dollars) }\end{array}$} & PC & $0.670^{* *}$ & $0.879^{* *}$ & $0.692^{* *}$ & -0.002 & 1 & $0.740^{* *}$ \\
\hline & $\mathrm{S}$ & 0.009 & 0 & 0.006 & 0.994 & 0.002 & \\
\hline & $\mathrm{CN}$ & 14 & 14 & 14 & 14 & 14 & 14 \\
\hline \multirow{3}{*}{$\begin{array}{l}\text { Actual utilization of } \\
\text { foreign capital (ten } \\
\text { thousand US dollars) }\end{array}$} & PC & 0.268 & 0.523 & 0.257 & -0.062 & $0.740^{* *}$ & 1 \\
\hline & $S$ & 0.355 & 0.055 & 0.375 & 0.833 & 0.002 & \\
\hline & $\mathrm{CN}$ & 14 & 14 & 14 & 14 & 14 & 14 \\
\hline
\end{tabular}

${ }^{* *}$ At the 0.01 level (two-tailed), the correlation is significant; *At the 0.05 level (two-tailed), the correlation is significant; PC: Pearson correlation; S: significance (two-tailed); $\mathrm{CN}$ : the case number.

variables. However, the correlation degree among the number of mobile phone users per 10,000 households, the number of fixed phone users per 10,000 households, and the total postal and telecommunications services of 10,000 yuan (TREND) at the end of the year is higher than 0.5 , indicating that there may be some multicollinearity among these variables. In summary, the independence between the two three-level indicators of traffic travel and communication is relatively reliable, but there are serious collinearity problems in both. Therefore, an indicator below the two indexes can be selected or synthesized to replace them.

4.2.3. Correlation of Relational Capital Variables. As shown in Table 7, the research on the relationship between the capital variables and the Pearson correlation test results shows that Pearson correlation coefficients for domestic tourist income $(\$ 10,000)$, total retail sales of social consumer goods (ten thousand yuan), number of domestic tourists (people), international tourist foreign exchange income (USD), and foreign direct investment (\$) are less than 0.6, and the two-tailed test probability $P$ value is greater than 0.15 .

Therefore, the domestic tourism income $(\$ 10,000)$, the total retail sales of social consumer goods (ten thousand yuan), the number of domestic tourists (people), the international tourist foreign exchange income (USD), and the foreign direct investment (\$) are significantly related to the domestic tourism income $(\$ 10,000)$ at the $5 \%$ level, while the actual use of pinch (dollars) at the 5\% level showed no significant correlation. The
Pearson correlation coefficients for the total retail sales of social consumer goods $(\$ 10,000)$, the number of domestic tourists (people), and the foreign direct investment (\$) are greater than 0.8 , with a two-tailed $P$ value of less than 0.01 ; thus, the total retail sales of social consumer goods $(\$ 10,000)$, the number of domestic tourists (people), and the foreign direct investment (\$) are significantly related to the total retail sales of social consumer goods $(\$ 10,000)$ and international tourist foreign exchange income (\$) at the $1 \%$ level, while the actual use of pinch (dollars) showed no significant correlation. Similarly, for the number of domestic tourists (people), international tourist foreign exchange income (USD), foreign direct investment (\$), and actual use of pinch (\$), only foreign direct investment (\$) and actual use of pinch (dollars) had Pearson correlation coefficients greater than 0.7 , with a two-tailed $P$ value of less than 0.01 ; thus, these two variables at the $1 \%$ level are positively and significantly related, while the rest of the variables at the $1 \%$ level showed no significant correlation. As seen from the figure, there may be a certain multicollinearity problem between the pair of relational capital variables. In summary, personnel exchanges and international and domestic trade between the three-level indicators are independent or relatively reliable, but in their personnel exchanges, domestic and international trade have had serious collinearity problems; thus, one can choose each of the three indicators or a synthetic index instead.

4.3. Robustness Analysis. Although the price of the above model test has shown that there are synergies between regional GDP and regional intellectual capital, the sample has 
endogeneity problems worth considering. Following the work of Wu Chaopeng, we use the human capital, structural capital, and relational capital time sequence extension values for our two-phase estimation method (2SLS) for verification. It can be seen that the fitting degree of the model obtained by adjusting the $R$ square value is $58.9 \%$, and the $P$ values of the $\mathrm{F}$ test and $t$-test are $0.011>0.01$ and $>0.05$, respectively, so there are no significant differences among the data, and the above regression equation model is still valid.

\section{Conclusions, Prospect Directions for Future Research, and Limitations}

5.1. Conclusions. Through an empirical analysis of the intelligence capital model and the corresponding model test, we can draw the following conclusions. First, we can see from Table 3 that three cities in Guangxi-Nanning, Liuzhou, and Guilin-appear to have the Pareto principle; in other words, these three cities possess most of the intellectual capital resources in the region, and the sum of the intellectual capital of other cities is less than the sum of that of these three cities. This finding means that the unbalanced characteristics of intellectual capital between cities have been quite prominent, and thus the alleviation of the unbalanced development of cities is urgently needed. Second, considering the comprehensive scores for regional intellectual capital and the levels of economic development of these 14 cities in Guangxi, it can be seen that, in terms of the highest structural capital impact on GDP, the government structure of capital income accounts for more than half of total revenue. Moreover, investment in structural capital can quickly improve a city's GDP to accelerate the development of the urban economy. This finding means that a city should concentrate most of its resources on the two directions of the transportation and communication of structural capital, while the development of human capital and relational capital needs only to meet the most basic needs temporarily.

5.2. Suggestions for Future Research. To improve the level of specific regional intellectual capital, human capital must be considered. A comparative analysis could be used to examine the relationship between capital structure and capital aspects to find the merits of the regional intellectual capital relative to other areas. Therefore, future work should aim to target development in line with the strategy of the development of regional advantages, foster strengths and circumvent weaknesses, and aid in the coordinated development across regions. According to the above basic principles, we put forward the following decision-making suggestions:

(1) Full play should be given to the advantages of regional structural capital, infrastructure construction should be improved, and a good development environment should be fostered. (1) Continuing to strengthen infrastructure construction at home to promote rapid economic growth: the following approaches should be taken: strengthening the construction in the field of communication and logistics; reasonably guiding the circulation of the population, goods, and information, with Nanning, Liuzhou, and Guilin as the core cities; spreading to major prefecture-level cities; and building a modern circulation network system in line with local conditions. (2) Complementing each other's advantages among regions to foster strengths and circumvent weaknesses: the following approaches should be taken: optimizing the regional industrial structure, realizing the complementarity and common development among different regions, constructing the modern industry self-circulation system among different regions in Guangxi, and realizing the purpose of common development. (3) Increase basic investment to improve the control, coordination, and management ability of the government in social and economic sectors; guarantee and continuously increase the proportion of local social security and public service fiscal expenditure; optimize the current social service institutions; and establish social auxiliary service institutions suitable for the era of knowledge economy.

(2) Attention should be paid to the cultivation of human capital and the protection of people's medical health. Strengthening investment in education, especially in the field of higher education: (1) talent has been an important booster in economic development in the era of the knowledge economy in the 21 st century. In the long run, the competition for talent in various regions will increase, and higher education is a convenient way to train local talent. At the same time, educational institutions should continue to adhere to and develop local vocational education and gradually shift to a sustainable, scientific, and technological innovation and intellectual capitaldriven new mode of economic growth. (2) Deepening the reform of medical and health services: the deepening of reform is the main driving force for current economic development. According to the original index data, the level of various medical indicators is still very different from the national average level, so it is necessary to guide the investment of private funds in the field of medical care.

(3) Regional relationship capital should be improved, and various systems and institutional arrangements should be optimized. Internal: one of the engines of economic growth is consumption. Through the reform of the market economy, especially the modern distribution system reform and the deepening of such reform, the income structure should be adjusted, the level of personnel security should be improved, especially for the purpose of raising the income level of low-income groups, and poverty alleviation work should be continued to intensify their spending power to stimulate consumption and local fast yet steady economic growth. (2) External: to promote social and economic development, foreign capital and exports should be considered 
externally. Second, we should deepen economic and trade cooperation with international regions, reasonably adjust the structure of foreign investment utilization and the demand structure of export markets, cultivate the core information technology and brand of an enterprise, and actively learn to integrate into the global high-end industrial chain. Finally, we should give full play to cooperation between countries, especially with ASEAN and "Silk Road" countries as the entry point, and to local and broader advantages to accelerate economic growth.

5.3. Limitations. The data selected are usually from the data published by the local statistics bureau, so the reliability and credibility of the data are guaranteed. However, the selection of intellectual capital indicators is restricted by the data and cannot be as representative as that of other scholars. Therefore, there are some limitations in the selection of our intellectual capital 90 measurement indicators, which cannot fully represent local intellectual capital.

\section{Data Availability}

All the data are from open databases (Guangxi Statistics Bureau of China and its affiliates). The data used to support the findings of this study are included within the supplementary information file.

\section{Conflicts of Interest}

The authors declare that there are no conflicts of interest regarding the publication of this paper.

\section{Acknowledgments}

The authors would like to acknowledge the support of the Guangxi Bureau of Statistics and its subordinate bureaus for their assistance in data collection and analysis. The authors also thank AJE (https://www.aje.cn/\#) for its linguistic assistance during the preparation of this manuscript. This work was supported by the National Natural Science Foundation of China (NSFC, Grant nos. 71663038 and 72064027).

\section{Supplementary Materials}

The data were obtained from the Guangxi Statistical Yearbook and the statistical yearbook of each prefecture-level city. At the time of calculation, in this paper, all data are in Supplementary Table 1 (intellectual capital raw data). (Supplementary Materials)

\section{References}

[1] S. C. Myers and S. M. Turnbull, "Capital budgeting and the capital asset pricing model: good news and bad news," Journal of Finance, vol. 32, no. 2, pp. 321-333, 1977.

[2] C. J. Collins and K. D. Clark, "Strategic human resource practices, top management team social networks, and firm performance," Academy of Management Journal, vol. 46, no. 6, pp. 740-751, 2003.

[3] J. K. Galbrait, "Professor gordon on "the close of the galbraith system"' Journal of Political Economy, vol. 77, no. 4, pp. 494-503, 1969.

[4] Y.-H. Hsu and W. Fang, "Intellectual capital and new product development performance: the mediating role of organizational learning capability," Technological Forecasting \& Social Change, vol. 76, no. 5, pp. 664-667, 2008.

[5] M.-C. Chen, S.-J. Cheng, and Y. Hwang, "An empirical investigation of the relationship between intellectual capital and firms' market value and financial performance," Journal of Intellectual Capital, vol. 6, no. 2, 2005.

[6] V. Masoulas, "Organisational requirements definition for intellectual capital management," International Journal of Technology Management, vol. 16, no. 1-3, pp. 126-143, 1998.

[7] A. Pulic, "VAIC ${ }^{\mathrm{TM}}$. an accounting tool for IC management," International Journal of Technology Management, vol. 20, no. 5-8, pp. 702-714, 2000.

[8] W.-M. Lu, Q. L. Kweh, and C.-L. Huang, "Intellectual capital and national innovation systems performance," KnowledgeBased Systems, vol. 71, pp. 201-210, 2014.

[9] L. Edvinsson and P. Sullivan, "Developing a model for managing intellectual capital," European Management Journal, vol. 14, no. 4, pp. 356-364, 1996.

[10] K. Bradley, "Intellectual capital and the new wealth of nations," London Business School Review, vol. 8, no. 1, pp. 53-62, 1997.

[11] S. Andriessen, "Intellectual capital of the European union," in Proceedings of the 7th McMaster World Congress on the Management of Intellectual Capital and Innovation, Ontario, Canada, June 2005.

[12] D. A. Garvin, "Building a learning organization," Harvard Business Review, vol. 71, no. 4, 1993.

[13] G. Schiuma, A. Lerro, and D. Carlucci, "The knoware tree and the regional intellectual capital index: an assessment within Italy," Journal of Intellectual Capital, vol. 9, no. 2, pp. 283-300, 2008.

[14] T. Nitkiewicz, P. Pachura, and N. Reid, "An appraisal of regional intellectual capital performance using data envelopment analysis," Applied Geography, vol. 53, pp. 246-257, 2014.

[15] P. Różewski and J. Jankowski, "Model of multilayer knowledge diffusion for competence development in an organization," Mathematical Problems in Engineering, vol. 201520 pages, 2015.

[16] K. Asiaei and R. Jusoh, "A multidimensional view of intellectual capital: the impact on organizational performance," Management Decision, vol. 53, no. 3, pp. 668-697, 2015.

[17] B. Cuozzo, J. Dumay, M. Palmaccio, and R. Lombardi, "Intellectual capital disclosure: a structured literature review," Journal of Intellectual Capital, vol. 18, no. 1, pp. 9-28, 2017.

[18] J. Flower, "The international integrated reporting council: a story of failure," Critical Perspectives on Accounting, vol. 27, pp. 1-17, 2015.

[19] J. Guthrie, R. Petty, and F. Ricceri, "The voluntary reporting of intellectual capital," Journal of Intellectual Capital, vol. 7, no. 2, pp. 254-271, 2013.

[20] W. Chen, Q. He, and X. Wang, "The relationship between national intellectual capital and national innovation capability_based on the 20 years' panel data of China," Forum on Science and Technology in China, vol. 2011, no. 4, 2011. 